\title{
ANALISA PERMASALAHAN BERBAGAI PLATFORM PINJAMAN DARING (PEER-TO-PEER LENDING) DAN PENANGANANNYA DI INDONESIA
}

\author{
Hapsari Wulandari ${ }^{1}$, Yumna Cahyaning ${ }^{2}$, Ardhi Dwi Firmansyah ${ }^{3}$, Brilliant Hartono ${ }^{4}$, \\ Rainal Yusril ${ }^{5}$, Nur Aini Rakhmawati ${ }^{6}$, Rahmat Hidayat ${ }^{7}$ \\ Departemen Sistem Informasi, Institut Teknologi Sepuluh Nopember, \\ Surabaya, 60111, Indonesia ${ }^{1,2,3,4,5,6,7}$ \\ Email : hapsari.17071@mhs.its.ac.id ${ }^{1}, 5216100074 @$ mahasiswa.its.ac.id ${ }^{2}$, \\ ardhi.17052@mhs.its.ac.id ${ }^{3}$, brilliant.17052@mhs.its.ac.id ${ }^{4}$,rainal.17052@mhs.its.ac.id ${ }^{5}$, \\ nur.aini@is.its.ac.id ${ }^{6}$,rahmat.19052@mhs.its.ac.id ${ }^{7}$
}

\begin{abstract}
ABSTRAK
Perkembangan teknologi informasi pada saat ini memiliki peran penting terhadap kebutuhan masyarakat. Adanya tuntutan pemenuhan kebutuhan yang meningkat dalam masyarakat menjadi salah satu faktor berdirinya perusahaan-perusahaan yang bergerak dalam peminjaman uang. Pertumbuhan teknologi yang semakin pesat menjadikan peminjaman uang semakin dipermudah, salah satunya peminjaman uang secara daring. Melalui data-data yang penulis dapatkan, masih terbuka celah bagi perusahaan yang berniat menyelewengkan tujuan dari adanya peminjaman secara daring. Pada penelitian ini akan dianalisa kasus pinjaman daring serta penangannya. Tujuan penelitian ini adalah untuk menganalisis perkembangan teknologi khususnya dalam bidang finansial. Adapun metodologi yang digunakan oleh penulis adalah studi pustaka dari berbagai literatur. Terjadinya berbagai masalah yang ada menyebabkan berbagai kasus permasalahan pada fintech pinjaman daring, berdasarkan data dari Otoritas Jasa Keuangan pada tahun 2018 - 2019, tingkat kasus transaksi yang statusnya adalah tidak lancar dan macet terus meningkat. Banyaknya pihak yang tidak memahami aturan beserta risiko dalam pelaksanaan pinjaman daring menyebabkan banyaknya kasus yang tidak terselesaikan. Hasil penelitian menunjukkan bahwa hanya 59\% ketercapaian perusahaan pinjaman daring dalam memenuhi peraturan yang berlaku.
\end{abstract}

Kata Kunci : financial technology, peer-to-peer lending, pinjaman daring.

\section{ABSTRACT}

The development of information technology currently has an important role to the needs of the community. The completion of meeting the increasing needs in the community is one factor in the establishment of companies engaged in lending money. Rapid technological growth that is easy to makes money lending, one of them is lender money by online system. Through the data obtained by the author, there is still a gap for companies that intend to mislead the objectives of the existence of borrowers with courage. The author tries to analyze the case of a brave loan and the handler. The purpose of this study is to analyze the development of special technology in the financial sector. From the results of the study used by the author is a literature study from various literatures. Various problems occur that cause various problems at fintech, bold loans, based on data from the Financial Services Authority in 2018 - 2019, the level of financial transactions whose status is not smooth and bad continues to increase. Many people who do not agree with regulations related to loans 
that dare to cause an amount that is not resolved. The results showed that only $59 \%$ of the success of online loan companies in meeting applicable regulations .

Keywords : financial technology, peer-to-peer lending, pinjaman daring.

\section{PENDAHULUAN}

Dewasa ini perkembangan dan pertumbuhan financial technology semakin pesat. Financial technology (fintech) atau dapat disebut teknologi finansial, merupakan inovasi teknologi yang bergerak di bidang jasa keuangan yang dapat menghasilkan model bisnis, aplikasi, proses atau produk baru dengan efek material terkait pada pasar keuangan, institusi, dan penyedia layanan keuangan. Terdapat satu jenis layanan yang sangat diminati yaitu Peer-to-peer Lending (P2P) atau dapat disebut sebagai pinjaman daring. Pinjaman daring (Peer-to-Peer Lending (P2P)/Crowdlending) merupakan penawaran pinjaman uang kepada peminjam secara daring dari pihak penyedia dana seperti perusahaan fintech, penyedia dana yang menggunakan media sosial (Facebook dan Twitter), dan berbagai penyedia dana yang menggunakan media lainnya (Bachmann dan Funk, 2015). Perusahaan pinjaman daring menyediakan pinjaman dengan bunga yang lebih rendah dan memberikan layanan dengan biaya yang lebih murah jika dibandingkan dengan perusahaan keuangan konvensional. Hal inilah yang menyebabkan peminat pinjaman daring terus meningkat. Tidak hanya pihak peminjam yang mendapatkan keuntungan, pihak pemberi pinjaman daring juga memperoleh keuntungan berupa keuntungan dari pembebanan biaya pinjaman setiap kali transaksi dilakukan. Sebagai hasilnya, pemberi pinjaman dapat memperoleh keuntungan yang lebih tinggi dibandingkan pinjaman yang ditawarkan oleh bank (Cunningham, 2013).

Telah muncul berbagai perusahaan teknologi finansial di Indonesia. Hingga 5 April 2019, terdapat 106 fintech lending yang sudah terdaftar di Otoritas Jasa Keuangan (OJK) (ojk.go.or.id). Namun, hanya 1 yang sudah diberikan izin oleh OJK, yaitu Fintech Danamas (Bachmann dan Funk, 2015). Hanya sedikit fintech lending yang dapat memenuhi izin pada OJK disebabkan persyaratan yang rumit dan sulit. Disinilah terdapat celah dimana perusahaan yang tidak sesuai dengan standar OJK dapat memanfaatkan kesempatan ini untuk melakukan berbagai kegiatan yang melanggar peraturan untuk mengakali para penggunanya. Contohnya adalah menyebarluaskan data nasabah untuk berbagai kepentingan, mempermainkan jumlah tagihan atau bunga yang dibebankan pada pelanggan dan sebagainya. Hal ini menandakan adanya celah keamanan pada platform pinjaman daring. Tidak hanya penyedia pinjaman daring atau perusahaan $\mathrm{P} 2 \mathrm{P}$ yang dapat melakukan pelanggaran. Nasabah atau peminjam dapat melakukan berbagai pelanggaran yang dapat menyebabkan kerugian pada perusahaan P2P. Bentukbentuk kecurangan yang dilakukan oleh peminjam adalah dana yang telah dipinjam tidak dikembalikan, melakukan penipuan dengan memalsukan identitas asli nasabah, mengganti nomor telepon genggam agar 
tidak bisa dihubungi dan sebagainya (Finansialku, 2016).

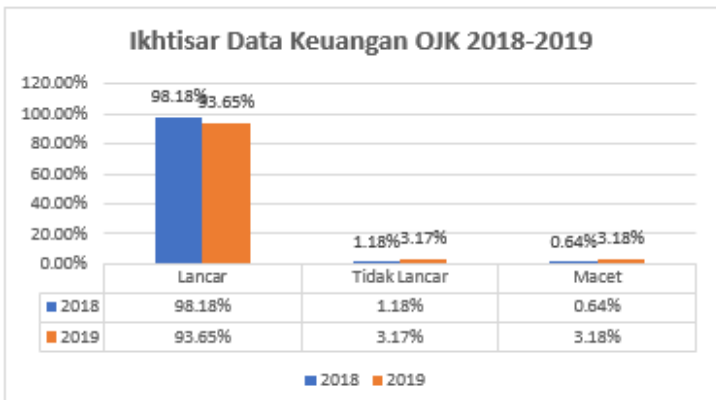

Gambar 1. Grafik Ikhtisar Keuangan OJK 2018-2019 (OJK, 2019)

Berdasarkan data yang diperoleh dari Ikhtisar Keuangan OJK tahun 2018-2019 yang dapat dilihat pada Gambar 1, dapat diketahui bahwa persenan transaksi yang tidak lancar (tidak terselesaikan dalam rentang waktu 30-90 hari) naik dari $1.18 \%$ pada tahun 2018 menjadi $3.17 \%$ pada tahun 2019. Sementara itu, transaksi yang macet (tidak terselesaikan dalam rentang waktu > 90 hari) naik dari $0.64 \%$ pada tahun 2018 menjadi $3.18 \%$ pada tahun 2019 (OJK, 2019). Hal ini tentu disebabkan oleh banyaknya pelanggaran yang tidak sesuai dengan standar OJK. Tidak lancarnya dan macetnya transaksitransaksi tersebut tentu disebabkan oleh berbagai hal.

Banyaknya pelanggaran dan berbagai permasalahan fintech $\mathrm{P} 2 \mathrm{P}$ yang terjadi disertai dengan terus meningkatnya pertumbuhan perusahaan $\mathrm{P} 2 \mathrm{P}$ tentu membuat keadaan pinjaman daring semakin rumit. Oleh karena itu, peraturan yang ada perlu diperhatikan dan dipahami betul-betul, baik oleh pemberi pinjaman maupun peminjam. Kedua belah pihak harus memahami risiko dan aturan pinjaman daring terlebih dahulu yang telah ditetapkan oleh OJK. Pada penelitian ini berfokus pada motivasi pendirian pinjaman daring oleh perusahaan $\mathrm{P} 2 \mathrm{P}$, motivasi menggunakan layanan pinjaman daring oleh nasabah, penyebab permasalahan pinjaman daring yang disebabkan oleh peminjam maupun perusahaan, solusi untuk permasalahan yang tidak lancar maupun macet (tidak dapat terselesaikan), tindak pencegahan agar permasalahan tidak terjadi dan tindakan preventif yang harus dilakukan oleh kedua belah pihak.untuk menciptakan fintech yang aman dan stabil. Salah satu tindakan preventif adalah edukasi. Edukasi penting untuk memahami seberapa banyak orang yang memiliki pengetahuan finansial dan sejauh mana pengetahuan mereka tentang keuangan mempengaruhi pengambilan keputusan keuangan mereka (Lusardi, 2019). Harapannya di waktu yang akan datang penerapan dan aktivitas pinjaman daring di Indonesia dapat berlangsung dengan lebih baik dan optimal.

\section{METODE PENELITIAN}

Diagram di bawah ini merupakan tahapan metodologi dalam penelitian.
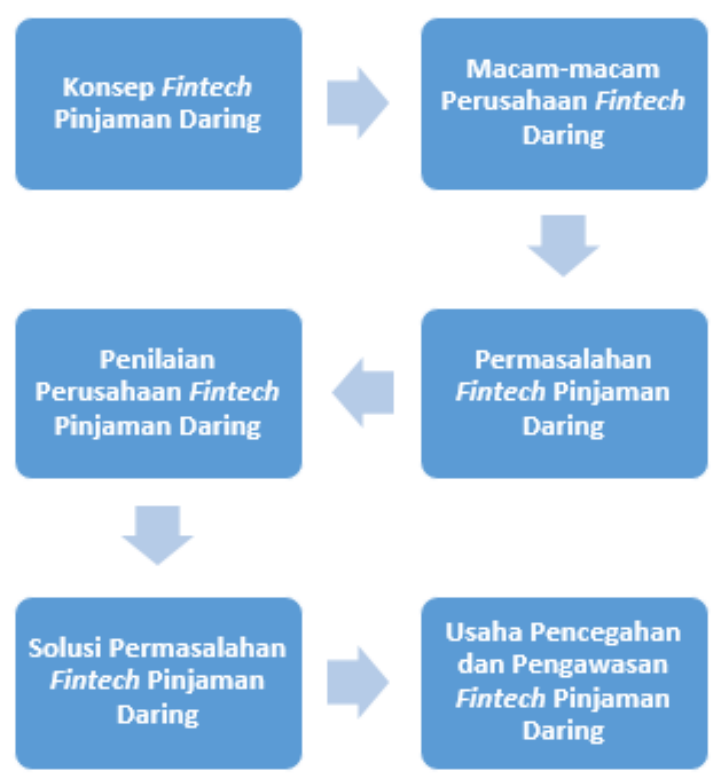

Gambar 2. Metodologi Penelitian 


\section{HASIL DAN PEMBAHASAN}

\subsection{Konsep Fintech Pinjaman Daring}

Pada tahun 2005 muncul sebuah konsep peer-to-peer lending dimana layanan peminjaman uang dilakukan secara daring. Istilah fintech pinjaman daring menjelaskan proses pinjaman antara individu pribadi pada platform online dimana lembaga keuangan keuangan hanya beroperasi sebagai perantara yang diwajibkan oleh hukum. Fintech pinjaman daring dilakukan oleh peminjam dan pemberi pinjaman pada sebuah platform seperti website atau mobile application untuk melakukan sebuah interaksi (Bachmann dan Funk, 2015).

Terdapat banyak keuntungan yang ditawarkan oleh platform pinjaman daring dibandingkan dengan transaksi pinjaman secara tradisional atau offline. Dapat diketahui bahwa investor yang menyongkong dana pada perusahaan pinjaman daring mendapatkan keuntungan lebih dari 10\% (Yuliarti, 2019).

3.2. Macam-macam Perusahaan Fintech Daring

Berbagai kategori Fintech di Indonesia yaitu sebagai berikut (Gideon, 2019) :

1. Pembiayaan berbentuk utang contohnya adalah UangTeman.com, TemanUsaha.com, Terhubung.com, BosTunai.com, Mekar.id, Tanihub.com, Taralite.com, Pinjam.co.id, Eragano.com, dan DrRupiah.com;

2. Pembiayaan berbasis patungan atau pembiayaan masal (crowdfunding) contohnya adalah Wujudkan.com, Kitabisa.com, Ayopeduli.com dan GandengTangan.org. WeCare.id, Indves.com, GandengTangan.org,
LimaKilo.id, iGrow.asia, Iwak.me, dan KapitalBoost.com;

3. Pembiayaan berbasis Peer to Peer Lending (P2P) contohnya adalah Koinworks.com, Amartha.com, DanaDidik.com, Crowdo.com, dan Investree.com;

4. Cicilan tanpa kartu kredit contohnya adalah Kredivo.com, ShootYourDream.com, dan Cicil.co.id.

\subsection{Permasalahan Fintech Pinjaman Daring}

Pada bagian ini, permasalahanpermasalahan yang dihadapi oleh perusahaan maupun peminjam layanan fintech pinjaman daring.

3.3.1. Masalah Perizinan dan Realibilitas

Banyak perusahaan pinjaman daring yang belum terdaftar OJK: perusahaan pinjaman daring yang tidak bergabung dengan OJK juga memiliki potensi merugikan masyarakat. OJK juga tidak dapat menertibkan dan menangani permasalahan yang diakibatkan oleh pinjaman daring liar tersebut. OJK hanya dapat memberi peringatan hingga mencabut izin, jika perusahaan pinjaman daring terdaftar dalam OJK (Pramesti, 2017). Selain itu, realibilitas aplikasi pinjaman daring juga dilihat apakah perusahaan tersebut terdaftar pada situt Penyelenggara Sistem Elektronik (PSE) atau tidak. Hal ini diwajibkan bagi seluruh perusahaan yang menyediakan layanan berupa jasa atau barang pada masyarakat (Utami, 2019).

3.3.2. Masalah Penagihan atau Pembebanan dengan Nominal yang Tidak Sesuai. 
1. Bunga terlalu tinggi: bunga tinggi merupakan permasalahan pinjaman daring yaitu ketika plafond (batas) pinjaman kecil, bunga tinggi tersebut pun menjadi terlihat kecil. Hal ini akan sangat merugikan peminjam dana. Tingginya bunga pinjaman pun juga terlambat diatur oleh OJK, sehingga muncul korban terlebih dahulu. Peminjam dana juga lengah karena tak menghitung bunga yang diberikan oleh pinjaman daring karena mencari kecepatan dan kemudahan dalam pinjaman daring (UU No 19 Tahun 2016).

2. Biaya tidak transparan: banyak dari perusahaan pinjaman daring yang juga tidak menampilkan biaya-biaya pinjaman secara transparan dan mudah diakses oleh peminjam dana (UU No 19 Tahun 2016).

3. Biaya admin terlalu tinggi: munculnya biaya admin yang tinggi menyebabkan permasalahan dalam pinjaman daring, sehingga saat pengembalian pinjaman pun akan terasa berat oleh peminjam dana. Dimana pada akhirnya peminjam tidak dapat membayar pinjaman daring tersebut (UU No 19 Tahun 2016).

4. Biaya keterlambatan terlalu tinggi: biaya keterlambatan yang diberikan oleh pinjaman daring juga memberikan dampak yang besar karena masih banyak peminjam dana yang membayar pinjaman tidak tepat waktu. Biaya keterlambatan ini-pun sangat besar bahkan bisa memiliki jumlah lebih besar dibanding pinjaman itu sendiri (UU No 19 Tahun 2016).

\subsubsection{Pelanggaran Hak Privasi}

1. Pelanggaran privasi: banyak aplikasi pinjaman daring yang melakukan penggalian data informasi pribadi peminjam dari perangkat mereka. Namun banyak peminjam yang tidak sadar hal ini saat aplikasi tersebut berjalan secara tersembunyi. Pada awal instalasi aplikasi pun, pengguna atau peminjam dana juga tidak sadar bahwa mereka memberikan hak akses terhadap informasi tersebut kepada aplikasi pinjaman daring (UU No 19 Tahun 2016). Disebutkan di dalam UU ITE Pasal 26 Ayat 1 (OJK, 2014) bahwa setiap penggunaan informasi melalui media elektronik yang menyangkut data pribadi seseorang harus dilakukan orang lain dengan persetujuan (UU No 19 Tahun 2016).

2. Pengambilan data diri yang berlebihan: pada beberapa aplikasi pinjaman daring, juga terdapat pengambilan informsi data diri yang berlebih, mulai dari data kontak telepon, SMS, lokasi, bahkan ada yang sampai mengambil data transaksi pada aplikasi taksi dan toko daring. Namun para peminjam dana pun tidak tahu bahwa mereka sedang diawasi oleh perusahaan pinjaman daring tersebut (UU No 19 Tahun 2016).

3. Penyebaran data pribadi dan privasi: setelah data pribadi dijadikan jaminan saat meminjam dana, pinjaman daring pun juga menjadikan data tersebut sebagai cara untuk memaksa peminjam yang belum mengembalikan pinjaman. Mulai dari menyebarkan data pribadi ke media sosial, hingga foto diri yang dijadikan lelucon orang dewasa dan disebar di media social (UU No 19 Tahun 2016).

\subsubsection{Pelanggaran Secara Fisik} dan Verbal 
Penagihan tidak sesuai aturan: banyak juga aplikasi daring yang menarik penagihan dengn cara yang tidak sesuai aturan, bahkan melanggar hak asasi manusia seperti pelecehan seksual, perkataan kasar, melakukan teror, bully, dan sebagainya (UU No 19 Tahun 2016).

\subsection{Penilaian Perusahaan Fintech} Pinjaman Daring

Pada tabel 1 terdapat kriteria penilaian perusahaan pinjaman daring sesuai dengan berbagai permasalahan yang telah dipaparkan pada subbab 3.3. Setiap permasalahan yang ada akan menghasilkan poin. Poin ini digunakan untuk penilaian terhadap perusahaan pinjaman daring. Pada

tabel 1 dapat dilihat setiap permasalahan akan menghasilkan poin berdasarkan kriteria yang telah ditetapkan.

Tabel 1. Kriteria Penilaian pada Permasalahan Pinjaman Daring

\begin{tabular}{llll}
\hline No. & $\begin{array}{l}\text { Kriteria } \\
\text { Penilaian }\end{array}$ & Syarat & Poin \\
\hline 1 & Aplikasi & Jika ada & 1 \\
\hline 2 & Website & Jika ada & 1 \\
\hline 3 & Jumlah & $\begin{array}{l}\text { Lebih dari } \\
100000 \\
\text { Download }\end{array}$ & 1 \\
\end{tabular}

\begin{tabular}{llll}
\hline 4 & $\begin{array}{l}\text { Rating } \\
\text { AppStore / } \\
\text { PlayStore }\end{array}$ & $\begin{array}{l}\text { Rating di } \\
\text { atas 3.2 }\end{array}$ & 1 \\
\hline 5 & Terdaftar PSE & $\begin{array}{l}\text { Jika } \\
\text { terdaftar }\end{array}$ & 1 \\
\hline 6 & Terdaftar OJK & $\begin{array}{l}\text { Jika } \\
\text { terdaftar }\end{array}$ & 1 \\
\hline 7 & $\begin{array}{l}\text { Tingkat } \\
\text { Keberhasilan } \\
\text { Bayar }\end{array}$ & $\begin{array}{l}\text { Jika } \\
\text { terdapat } \\
\text { informasi }\end{array}$ & 1 \\
\hline
\end{tabular}

\begin{tabular}{llll}
\hline 8 & $\begin{array}{l}\text { Bunga } \\
\text { Maksimal }\end{array}$ & $\begin{array}{l}\text { Jika } \\
\text { terdapat } \\
\text { informasi }\end{array}$ & 1 \\
\hline 9 & $\begin{array}{l}\text { Biaya Tidak } \\
\text { Transparan }\end{array}$ & Jika tidak & 1 \\
\hline 10 & $\begin{array}{l}\text { Biaya } \\
\text { Keterlambatan } \\
\text { Maksimal }\end{array}$ & $\begin{array}{l}\text { Jika } \\
\text { terdapat } \\
\text { informasi }\end{array}$ & 1 \\
\hline 11 & $\begin{array}{l}\text { Pelanggaran } \\
\text { Privasi }\end{array}$ & $\begin{array}{l}\text { Jika tidak } \\
\text { melakukan }\end{array}$ & 1 \\
\hline & $\begin{array}{l}\text { Pengambilan } \\
\text { Data Diri } \\
\text { yang } \\
\text { Berlebihan }\end{array}$ & $\begin{array}{l}\text { Jika tidak } \\
\text { melakukan }\end{array}$ & 1 \\
\hline 13 & $\begin{array}{l}\text { Penyebaran } \\
\text { Data Pribadi } \\
\text { dan Privasi }\end{array}$ & $\begin{array}{l}\text { Jika tidak } \\
\text { melakukan }\end{array}$ & 1 \\
\hline & $\begin{array}{l}\text { Penagihan } \\
\text { Tidak Sesuai } \\
\text { Aturan }\end{array}$ & Jika tidak \\
melakukan & 1 \\
\hline & & & \\
\hline
\end{tabular}

Pada penelitian ini, 19 perusahaan fintech digunakan sebagai sampel yaitu Kredivo, KoinWorks, TunaiKita.com, Akulaku, dan sebagainya. Pada tabel 2 terdapat analisa terhadap setiap perusahaan fintech apakah perusahaan tersebut memenuhi berbagai kriteria sesuai dengan tabel 1 seperti terdaftar pada OJK, tingkat keberhasilan pembayaran, terdapat website, terdapat aplikasi dan sebagainya. Setiap perusahaan pinjaman daring akan dinilai berdasarkan pemenuhan kriteria sesuai dengan tabel 1 . Total poin maksimal yang dapat diperoleh adalah 14 poin, dimana nilai akhir didapatkan dari total poin lalu dibagi 14 kriteria sehingga nilai maksimal adalah 100 .

Data-data pada tabel 2 diperoleh dari website masing-masing perusahaan dan sumber informasi lainnya seperti website OJK, website PSE, dan lainnya. Berdasarkan tabel 2, dapat diketahui bahwa rata-rata nilai yang dihasilkan adalah 59 dari skala 100. Hal ini menunjukkan bahwa dari sampel yang 
digunakan, hanya $59 \%$ ketercapaian perusahaan pinjaman daring dalam mematuhi peraturan.

Pada gambar 3 dapat diketahui bahwa hanya $47 \%$ perusahaan yang memiliki nilai di atas $70,16 \%$ perusahaan memiliki nilai di antara 50 - 69 dan sisanya sebanyak $37 \%$ perusahaan memiliki nilai di bawah 49. Hal ini menandakan bahwa probabilitas masyarakat memilih fintech berkualitas rendah akan semakin tinggi disebabkan jumlah fintech yang bernilai kecil berjumlah cukup banyak.
Persebaran Nilai Perusahaan Pinjaman Daring

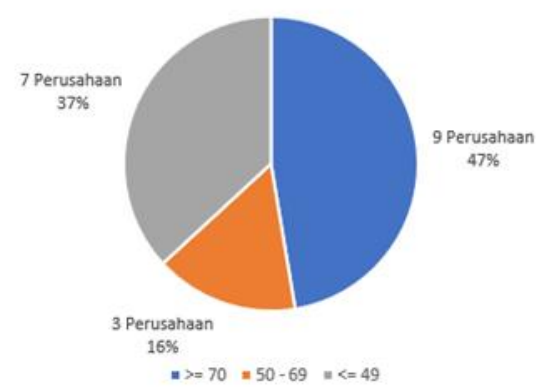

Gambar 3. Persebaran Nilai Perusahaan Pinjaman Daring

Tabel 2. Kriteria Penilaian pada Permasalahan

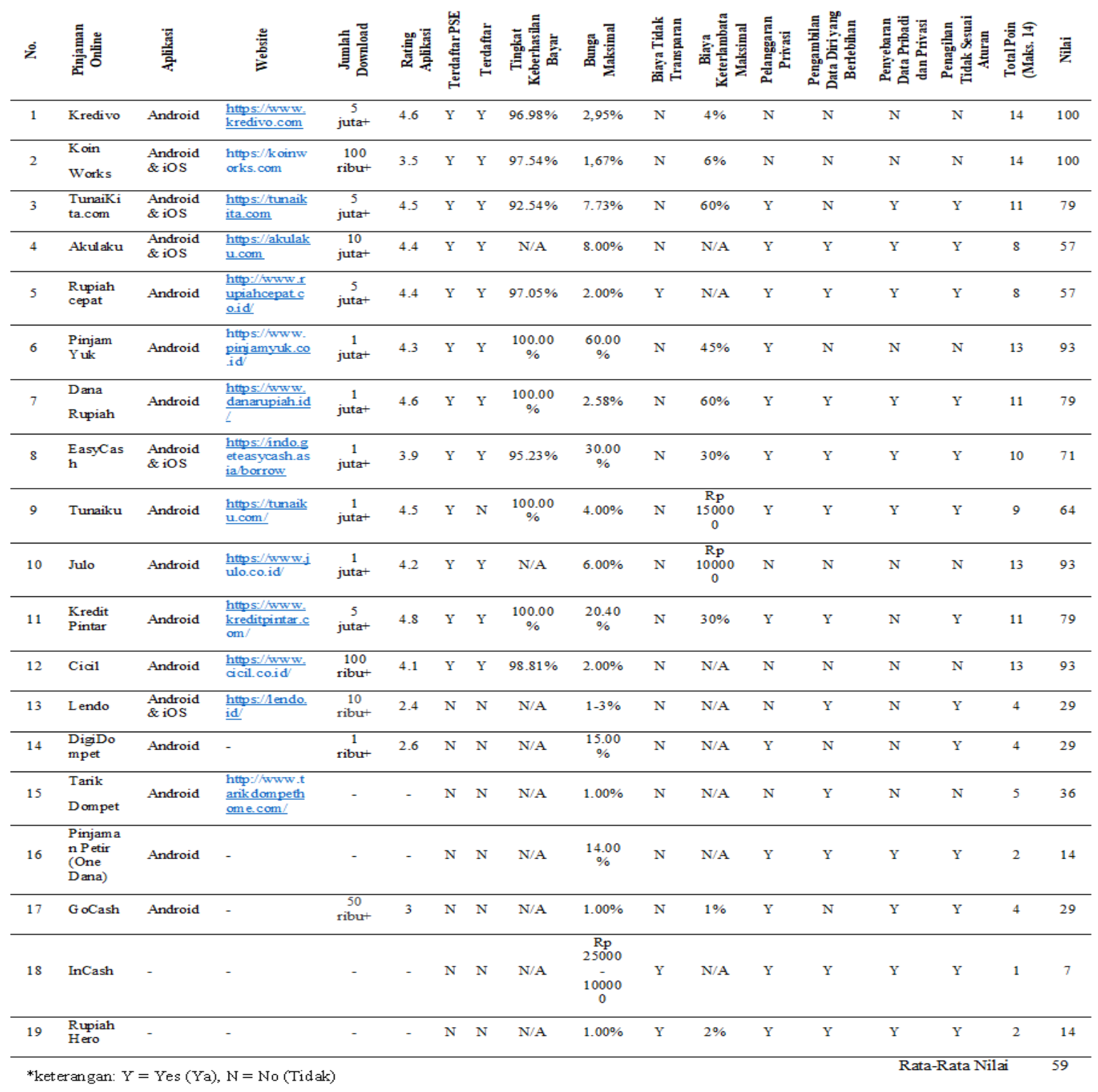


Meskipun 12 dari 19 perusahaan yang digunakan sebagai sampel telah terdaftar pada OJK, namun hanya 58\% atau 7 perusahaan yang memiliki nilai di atas $70.42 \%$ atau 5 perusahaan lainnya bernilai di bawah 70 yang dapat dilihat pada gambar 4. Hal ini menunjukkan bahwa meskipun perusahaan pinjaman daring telah terdaftar di OJK, tidak menjamin bahwa perusahaan pinjaman daring tersebut memiliki kualitas yang baik. Masyarakat Indonesia harus berhatihati dan mempelajari lebih dalam pada masing-masing perusahaan pinjaman daring agar tidak terjebak pada hal-hal yang tidak diinginkan.

Persebaran Nilai Perusahaan Terdaftar OJK

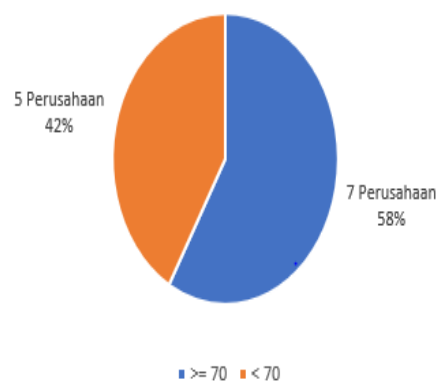

Gambar 4. Persebaran Nilai Perusahaan

Pinjaman Daring Terdaftar OJK

Saat memimnjam uang dari perusahaan pinjaman daring, para peminjam pun harus memperhatikan bunga dan biaya keterlambatan yang perlu dibayarkan. Ketika nasabah terlambat membayarkan angsuran, biasanya terdapat denda atau bunga yang perlu dibayarkan sesuai dengan durasi keterlambatan atau dapat disebut 'Biaya Keterlambatan Maksimal'. Sebanyak 8 perusahaan tidak menampilkan biaya keterlambatan dan 5 perusahaan menetapkan biaya keterlambatan di atas $10 \%$ dari jumlah pinjaman setiap bulannya. Hal ini merupakan suatu permasalahan karena dapat menimbulkan jumlah bunga yang sangat besar dan dapat menyebabkan nasabah tidak dapat membayar. Tidak adanya informasi juga menyebabkan penetapan bunga yang tidak valid serta dapat dipermainkan atau diubah oleh perusahaan pinjaman daring.

Untuk 'Bunga Maksimal', dari 19 sampel yang diteliti semua perusahaan pinjaman daring menyertakan informasi bunga pinjaman. Namun, besaran bunga tetap harus diperhatikan karena ada beberapa pinjaman daring yang menetapkan bunga di atas $10 \%$, bahkan ada yang lebih dari 50\%. Hal ini tentu akan memberatkan peminjam untuk mengembalikan dana, terutama apabila peminjam tidak mengetahui besaran bunga tersebut sebelum meminjam dana.

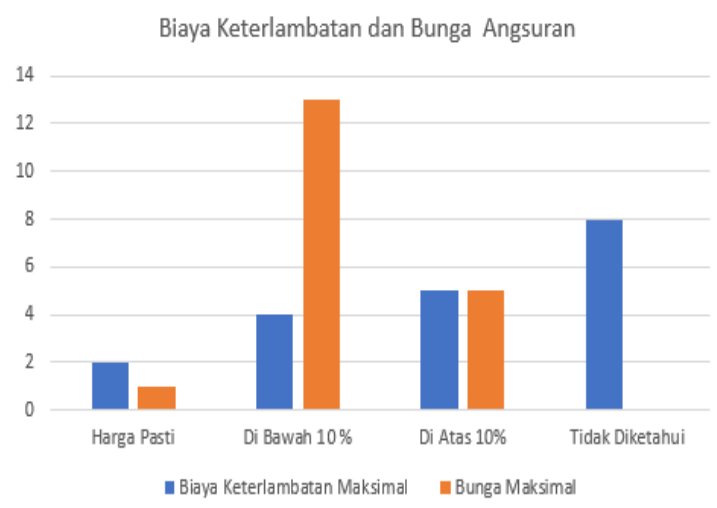

Gambar 5. Informasi Mengenai Biaya Keterlambatan

3.5. Solusi Permasalahan Fintech Pinjaman Daring

Solusi serta penanganan akan dijelaskan berdasarkan permasalahan. Penelitian ini dilakukan dengan tujuan agar di masa yang akan datang, masalah-masalah tersebut dapat diselesaikan secara komprehensif dan sesuai dengan landasan hukum yang berlaku di Indonesia. Setelah mengetahui berbagai permasalahan yang terjadi pada pinjaman daring, pengelompokkan permasalahan beserta solusinya dipaparkan pada tabel 3. 
Tabel 3. Solusi Terhadap Permasalahan Pinjaman Daring

\begin{tabular}{|c|c|c|c|}
\hline No. & Permasalahan & $\begin{array}{c}\text { Kelompok } \\
\text { Permasalahan }\end{array}$ & Solusi \\
\hline 1 & $\begin{array}{l}\text { Banyak } \\
\text { Perusahaan } \\
\text { Pinjaman } \\
\text { Daring yang } \\
\text { Belum } \\
\text { Terdaftar OJK }\end{array}$ & Perizinan & $\begin{array}{l}\text { Perusahaan pinjaman } \\
\text { daring seharusnya } \\
\text { berusaha untuk } \\
\text { mendaftarkan usahanya } \\
\text { dan mendapatkan izin. } \\
\text { Sebagaimana telah diatur } \\
\text { pada Peraturan Otoritas } \\
\text { Jasa Keuangan (OJK) } \\
\text { Nomor 12/POJK.05/2014 } \\
\text { ( Peraturan Pemerintah } \\
\text { Nomor } 89 \text { Tahun 2014) } \\
\text { tentang perizinan usaha } \\
\text { dan kelembagaan } \\
\text { lembaga keuangan mikro. }\end{array}$ \\
\hline 2 & $\begin{array}{l}\text { Bunga Terlalu } \\
\text { Tinggi }\end{array}$ & $\begin{array}{l}\text { Penagihan atau } \\
\text { pembebanan }\end{array}$ & $\begin{array}{l}\text { Sebagai mana telah diatur } \\
\text { dalam Peraturan }\end{array}$ \\
\hline 3 & $\begin{array}{l}\text { Biaya Tidak } \\
\text { Transparan }\end{array}$ & dengan & $\begin{array}{l}\text { Pemerintah Nomor } 89 \\
\text { Tahun } 2014 \text { [13], }\end{array}$ \\
\hline 4 & $\begin{array}{l}\text { Biaya } \\
\text { Keterlambatan } \\
\text { Terlalu Tinggi }\end{array}$ & tidak sesuai & $\begin{array}{l}\text { seharusnya perusahaan } \\
\text { pinjaman daring } \\
\text { memberikan bunga yang } \\
\text { sesuai dengan peraturan. }\end{array}$ \\
\hline 5 & $\begin{array}{l}\text { Pelanggaran } \\
\text { Privasi }\end{array}$ & $\begin{array}{l}\text { Pelanggaran } \\
\text { hak privasi }\end{array}$ & $\begin{array}{l}\text { Sesuai dengan } \\
\text { UU ITE Pasal } 30\end{array}$ \\
\hline 6 & $\begin{array}{l}\text { Pengambilan } \\
\text { Data Diri yang } \\
\text { Berlebihan }\end{array}$ & & $\begin{array}{l}\text { ayat } 1 \text { (OJK, } \\
\text { 2014), perusahaan } \\
\text { pinjaman daring } \\
\text { harus memahami }\end{array}$ \\
\hline 7 & $\begin{array}{l}\text { Penyebaran } \\
\text { Data Pribadi } \\
\text { dan Privasi }\end{array}$ & & $\begin{array}{l}\text { bahwa data-data } \\
\text { yang telah diinput } \\
\text { oleh pengguna } \\
\text { atau nasabah } \\
\text { harus dijaga } \\
\text { kerahasiaannya. }\end{array}$ \\
\hline
\end{tabular}

Berdasarkan tabel 3, dapat diketahui bahwa sebenarnya solusi dari permasalahan yang dapat dilakukan oleh perusahaan pinjaman daring adalah dengan mematuhi peraturan-peraturan yang sudah ditetapkan oleh lembaga hukum di Indonesia. Kesadaran akan adanya undang-undang tersebut kurang diperhatikan oleh pihak-pihak yang terlibat pada perusahaan pinjaman daring. Oleh karena itu, diperlukan pendalaman secara komprehensif untuk menekan seluruh permasalahan yang terjadi pada pinjaman daring.

Selain itu, nasabah atau peminjam harus lebih berhati-hati dayyn teliti dalam memilih fintech. Peminjam harus memahami latar belakang, informasi mengenai fintech tersebut apakah terpercaya atau tidak. Selain itu nasabah juga perlu mencari tahu besaran bunga dan biaya keterlambatan yang harus dibayarkan. Dengan memperhatikan berbagai kriteria tersebut, dapat membantu mencegah terjadinya permasalahan yang tidak diinginkan seperti keterlambatan atau kesulitan pembayaran angsuran, penagihan yang tidak sesuai dengan aturan dan sebagainya.

3.6. Usaha Pencegahan dan Pengawasan Fintech Pinjaman Daring

Otoritas Jasa Keuangan melakukan beberapa tindakan preventif dalam mengatasi beberapa permasalahan fintech. Pada gambar 5 terdapat beberapa tindakan yang dilakukan oleh Otoritas Jasa Keuangan dalam melakukan pencegahan dan pengawasan pada perusahaan fintech di Indonesia.

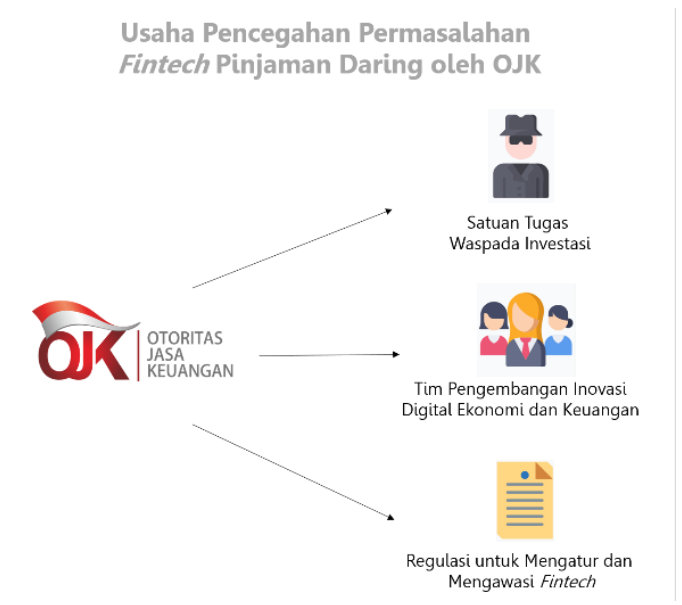

Gambar 6. Pencegahan Permasalahan

Fintech Pinjaman Daring oleh OJK

Otoritas Jasa Keuangan membentuk sebuah Satuan Tugas atau Satgas yang diberi nama Satgas Waspada Investasi (UU No 19 Tahun 2016). Satgas ini dibentuk berdasarkan keputusan dewan komisioner otoritas jasa keuangan nomor: 01/KDK.01/2016 tanggal 1 Januari 2016. Satuan tugas melakukan penanganan dugaan tindakan melawan hukum di bidang penghimpunan dana masyarakat 
dan pengelolaan investasi. Tindak pencegahan yang dilakukan satgas ini berupa edukasi dan sosialisasi pada para pelaku industri jasa keuangan. Sesuai dengan Undang-Undang Nomor 21 Tahun 2011, Otoritas Jasa Keuangan (OJK) telah menyiapkan sejumlah regulasi untuk mengatur dan mengawasi perkembangan jenis usaha sektor jasa keuangan yang menggunakan teknologi atau fintech. Otoritas Jasa Keuangan juga telah membuat Tim Pengembangan Inovasi Digital Ekonomi dan Keuangan yang terdiri dari gabungan beberapa satuan kerja untuk mengkaji dan mempelajari perkembangan serta aturan bagi fintech.

Otoritas Jasa Keuangan mengeluarkan peraturan baru terkait fintech yaitu Nomor 13/POJK.02/2018 tentang Inovasi Keuangan Digital di Sektor Jasa Keuangan dikeluarkan sebagai ketentuan yang memayungi pengawasan dan pengaturan industri fintech. Terdapat 9 pokok pengaturan inovasi keuangan digital (IKD) yang terdapat pada peraturan tersebut , meliputi:

1. Mekanisme Pencatatan dan Pendaftaran Fintech

2. Mekanisme Pemantauan dan Pengawasan Fintech

3. Pembentukan Ekosistem Fintech

4. Membangun Budaya Inovasi dan Kolaborasi

5. Inklusi dan Literasi

6. Manajemen Risiko yang Efektif

7. Perlindungan Konsumen

8. Transparansi

9. Anti-Pencucian Uang dan Pendanaan Terorisme

Dengan berbagai tindakan yang telah dilakukan oleh Otoritas Jasa Keuangan, diharapkan permasalahan yang terjadi baik yang dialami oleh nasabah atau peminjam maupun penyedia dapat dicegah dan diselesaikan.

\section{KESIMPULAN}

Indonesia merupakan pasar yang memiliki potensi pengembangan layanan pinjaman daring karena terdapat peminat berjumlah tinggi, oleh karena itu apabila risiko dan permasalahan dapat ditekan, sangat mungkin jenis layanan ini akan terus memberikan keuntungan bagi kedua belah pihak yaitu peminjam dan penyedia dana pinjaman daring. Fintech adalah gabungan dari jasa keuangan dengan teknologi yang awalnya membayar harus bertatap muka dan membawa sejumlah uang, kini dapat dilakukan dengan cara transaksi jarak jauh hingga dapat dilakukan dalam hitungan detik saja. Fintech muncul dikarenakan adanya perubahan gaya hidup masyarakat, yaitu saat ini masyarakat didominasi oleh teknologi informasi dari tuntutan pekerjaan maupun. Dalam pelaksanannya, fintech mengalami banyak permasalahan, mulai dari sisi perusahaan, hingga pada sisi nasabah. Banyak perusahaan yang tidak terdaftar resmi pada Otoritas Jasa Keuangan (OJK) dan Penyelenggara Sistem Elektronik (PSE). Selain itu, walaupun beberapa perusahaan lainnya sudah terdaftar secara resmi pada kedua lembaga tersebut, tetap saja masih banyak pelanggaran dan peraturan yang tidak dipatuhi oleh perusahaan sehingga menimbulkan berbagai permasalahan yang merugikan peminjam dan penyedia dana. Peminjam atau nasabah harus meningkatkan kesadaran terhadap kualitas perusahaan pinjaman daring yang akan 
dipilih untuk meminjam dana. Untuk mengatasi segala permasalahan yang terjadi, dibutuhkan pihak ketiga sebagai regulator yang membantu kegiatan pinjaman secara daring yaitu OJK dan undang-undang serta peraturan yang mengatur kegiatan pinjaman daring. Wewenang OJK terdapat dalam Pasal 9 UU No.21 Tahun 2011 yaitu: kewenangan memberi izin, kewenangan untuk mengatur, kewenangan untuk mengawasi, dan kewenangan untuk mengenakan sanksi. Kewenangan-kewenangan itu harus diikuti oleh Lembaga keuangan termasuk perusahan fintech. OJK memberikan regulasi-regulasi agar permasalahan yang terjadi pada dunia fintech dapat diminimalisir.

Berdasarkan hasil Analisa yang telah dilakukan terhadap 19 aplikasi yang beredar saat ini menunjukkan nilai ratarata akhir yaitu 59 dari skala 100. Merujuk pada hasil yang didapatkan tersebut, menunjukkan bahwa hanya $59 \%$ ketercapaian perusahaan pinjaman daring dalam memenuhi peraturan yang berlaku. Meskipun jumlah aplikasi yang terdaftar pada OJK sebanyak 12 aplikasi dari 19 aplikasi, namun hanya 58\% atau 7 aplikasi yang memiliki nilai diatas 70. Sehingga meskipun ada beberapa aplikasi yang sudah terdaftar di OJK, namun tidak dapat menjamin aplikasi pinjaman daring tersebut memiliki kualitas yang baik. Selain itu, dikarenakan fintech yang bernilai kecil memiliki jumlah yang cukup banyak, maka peluang masyarakat dalam memilih aplikasi pinjaman daring yang berkualitas rendah akan akan semakin tinggi. Maka dari itu, sebaiknya masyarakat Indonesia lebih berhati-hati dan mempelajari lebih dalam aplikasi yang akan dipilih untuk pinjaman daring.

\section{DAFTAR PUSTAKA}

A. Bachmann and B. Funk, "Journal of Internet Banking and Commerce," no. January 2011, 2015.

A. Gideon, “1.230 Fintech Ilegal Beroperasi di RI, 42 Persen Taruh Server di Luar Negeri," 2019. [Online]. Available: https://www.liputan6.com/bisnis/re $\mathrm{ad} / 4028402 / 1230$-fintech-ilegalberoperasi-di-ri-42-persen-taruhserver-di-luar-negeri. [Accessed: 23-Sep-2019].

A. Lusardi, "Financial literacy and the need for financial education: evidence and implications," vol. 5, pp. 1-8, 2019.

D. F. Utami, "7 Risiko Pinjaman Online," 2019. [Online]. Available: https://www.finansialku.com/7risiko-pinjaman-online/. [Accessed: 23- Sep-2019].

Finansialku, "Apa Itu Industri Financial Technology (Fintech Indonesia)," 2016. [Online]. Available: https://www.finansialku.com/apaitu-industri-financial-technologyfintech-indonesia/. [Accessed: 17Sep-2019].

OJK, "Ikhtisar-Keuangan-Fintech-(PeerTo-Peer-lending)-Periode-Februari2019,” 2019. [Online]. Available: https://www.ojk.go.id/id/kanal/iknb /data-danstatistik/fintech/Pages/IkhtisarKeuangan-Fintech-(Peer-To-Peerlending)-Periode-Februari-

2019.aspx. [Accessed: 23-Sep2019].

OJK, Peraturan Otoritas Jasa Keuangan (OJK) Nomor 12/POJK.05/2014. 2014. 
Simon Cunningham, "What is an expected return in peer to peer lending? 2013. [Online]. Available: https://www.lendingmemo.com/pe er-to-peer-lending-return/. [Accessed: 23-Sep-2019].

T. J. A. Pramesti, "Penyelenggara Sistem Elektronik yang Wajib Melakukan Pendaftaran," 2017. [Online]. Available:

https://www.hukumonline.com/klin $\mathrm{ik} /$ detail/ulasan/lt598832e6a5643/p enyelenggara-sistem-elektronikyang-wajib-melakukanpendaftaran/. [Accessed: 23-Sep2019].

Pemerintah Pusat Republik Indonesia, Undang-Undang Republik Indonesia Nomor 19 Tahun 2016. 2016.

Pemerintah Pusat Republik Indonesia, Peraturan Pemerintah Nomor 89 Tahun 2014. 2014.

W. Yuliarti, "Finansialku Perencana Keuangan Independen," 2019. [Online]. Available: https://www.finansialku.com/kelua r-dari-pinjol/. [Accessed: 23-Sep2019]. 